（日本化学会誌, 1975, (12), p. 2183 2187)

\title{
酸化タングステンーシリカ触媒による $\mathrm{C}_{4}$ オレフィンの共不均化
}

(1975 年 5 月 19 日 受 理)

高橋 忠 雄*

原料モル比 1:1の 2 成分系 $\mathrm{C}_{4}$ オレフィン混合物の $\mathrm{WO}_{8}-\mathrm{SiO}_{2}$ 触媒上に拈ける共不均化反応につい て,オレフィンの組久合わせの異なる打の打のの系の, 各種の一次メタセシスの初速度比を求めた。その 初速度此は, $450^{\circ} \mathrm{C}$ 亿招いて,1-ブテンーイソブチレン系では, $r_{1 \mathrm{~B}-1 \mathrm{~B}}: r_{1 \mathrm{~B}-\ell \mathrm{B}}: r_{\mathrm{iB}-\ell \mathrm{B}}=90: 50: 1$, cis-2ブテンーイソブチレン系では, $r_{\mathrm{cB}-\ell \mathrm{B}}: r_{\mathrm{iB}-\mathrm{lB}}=100: 1$, trans-2-ブテンーイソブチレン系では, $r_{t \mathrm{~B}-\ell \mathrm{B}}:$ $r_{i \mathrm{~B}-t \mathrm{~B}}=120: 1$ であった。1-ブテンーcis-2-ブテン系拉よび 1-ブテンーtrans-2-ブテン系に拈いては $r_{1 \mathrm{~B}-1 \mathrm{~B}}: r_{1 \mathrm{~B}-C \mathrm{~B}}=r_{\mathrm{BB}-1 \mathrm{~B}}: r_{\mathrm{BB}-t \mathrm{~B}}=1: 6$ であった。

3 種の 2 成分系直鎖ブテンーイソブチンン系について，原料組成と生成物組成の関係を調べた。この 研究の反応条件に打いては，二重結合の異性化がかなり急速に進行したので，不均化反応の選択性は低 かった。2-ブテンーイソブチレン系の反応による生成 $\mathrm{C}_{5}$ オレフィンのイソアミレン選択率を高めるた めには，インブチレンの比較的高濃度の原料を用いる必要がある。

\section{1 緒 言}

イソブチレンとプロピレンあるいは 2-ブテンの共不均化反応 は，イソアミレンの合成方法として注目されているが(1)2)，この ような反応系において起こる各種の反応の相互関保については， ほとんど明らかにされていない。 $\mathrm{WO}_{8}-\mathrm{SiO}_{2}$ 触某によるブロピレ ンとインブチンンの共不均化炕ついては，既報》において，3種 の一次メタセシスの初速度比，原料組成と生成物組成の関係など について述べた。

本報においては，直鎖ブテン類およびイソブチレンの組み合わ せに上る2成分系オンフィン湿合物の $\mathrm{WO}_{3}-\mathrm{SiO}_{2}$ 触媒上に枋ける 共不均化について実験を行ない, 組成比が $1: 1$ の原料を用いた さいの一次メタセシスの初速度比を求め，また，原料組成と生成 物組成の関保について調べた。これらの結果について，既報の結 果とも比較して述べる。な⿰扌，本報に抋いても，総括的には不均 化または共不均化といら言葉を用い，個なの反応を論ずる場合に は,メタセシスといら語を用いた。

\section{2 実験}

実験は既報》の方法とほ注同様に行なった。使用した触媒は， 含漫法によって調製したもので，既報の含漫触媒と同一ロットの WO $8 \mathrm{wt} \%$ のものである。反応装置む既報と同じるので，石英 ガラス慜の反応管は内径 $20 \mathrm{~mm}$ のむのを用いた。原料オレフィ ンは, いずれも高压容器入りのものを，反応装置に付属した $3 \mathrm{~A}$

* 公害凟源研究所, 332 川口市版口

1) R. L. Banks, R. B. Regier, I. E.C. Prod. Res. Develop., 10, 46(1971).

2) R. Nakamura, H. Iida, E. Echigoya, Chem. Lett., 1972, 273.

3）謟橋忠雄，日化，1975，1058.
型合成ゼオライト乾燥器を通して乾燥して用いた。原料オレフィ ンの分析結果を表 1 に示す。

反応生成物の分析も既報と同棣に行なった。すなわち，反応管 から流出するオレフィン混合物に，直接 1.5〜2 倍量の水素を混 合し, $\mathrm{Pd}-\mathrm{Al}_{2} \mathrm{O}_{\mathrm{g}}$ 触媒上を通して水素化したのち，飽和炭化水素 としてガスクロマトグラフによって分析する方法かを主とし，直 接的なオレフィンのガスクロマトグラフによる分析を補助的な手 段として用いた。各反応条件を代表する生成物の分析值の決め方 などす既報に準じて行なっだ。

\section{3 結果および考察}

3.1 直鋿ブテン類-イソブチレンのモル比 $1: 1$ の原料を用い た場合の一次メタセシスの初速度比

$\mathrm{WO}_{8}-\mathrm{SiO}_{2}$ 触媒によるプロピレンの不均化反応は, 線速度依存 性が高く，触媒粒子外拡散律速となること占6)が報告されている。

Table 1 Compositions (mol $\%$ ) of the olefins used in these experiments

Component $\begin{gathered}1- \\ \text { Butene }\end{gathered} \begin{gathered}c i s-2- \\ \text { Butene }\end{gathered} \begin{gathered}\text { trans-2- } \\ \text { Butene }\end{gathered}$ Isobutylene

\begin{tabular}{lrrr}
\hline Propane+Propylene & 0.14 & & 0.06 \\
Butane & 0.20 & 0.04 & 0.01 \\
Isobutane & 0.17 & & 0.07 \\
1-Butene & 99.23 & 0.01 & 1.02
\end{tabular}

cis-2-Butene trans-2-Butene

0.01

99.81 Isobutylene

0.25

99.95

0.02

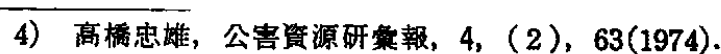

5) A.J. Moffat, M. M. Johnson, A. Clark, J. Catal., 18, 345(1970).

6) A. J. Moffat, A. Clark, M. M. Johnson, ibid., 22, 379 (1971). 
プロピレンーイソブチレン系においてむ,このよ5な現象が観察さ れ゙，また後で述べるように，1ーブテンの不均化に括いても明ら かにこの現象が認められる。C にも，この現象の例外となることは考えられないので，反応速度 の物質移動依存性とは関係なしK，その相対値を求めることのて きる既報で用いた方法を，本報に批いても採用した。すなわち， イソブチン転化率と各一次メタセシス生成物の関係のプロットの

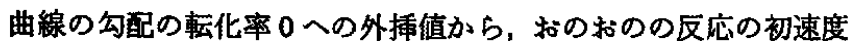
比を求める方法によって，1-ブテンーインブチレン系, cis-2-ブ テンーイソブチレン系, および trans-2-ブテンーイソブチレン

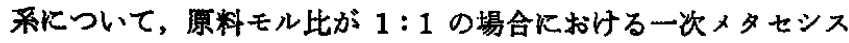
の初速度比を求めた。このための実験は反応温度 $450^{\circ} \mathrm{C}$, 触桇量 $0.5 \sim 2.0 \mathrm{~g}$ ，原料流量 18 または $20 \mathrm{l} / \mathrm{hr}$ ，NTPで行なった。

1ーブテンーイソブチレン系の反応生成物は，まず，一次メタセ シス生成物として，1ーブテン 2 分子からのエチレン拉よび 3-へ キセン類，1ーブテンとイソブチレンのメタセシスによるエチレン と 2-メチル-2-ペンテン, およびイソプチレン同志のメタセシス によるエチレンを 2,3-ジメチル-2-ブテンがある。これらの活か K, 1-ブテンの二重結合異性化物の 2-ブテン類と 2-ブテンの関 与するメタセシス生成物，すなわち，1-ブテンと 2-ブテンの反応 によるプロピレンと 2-ベンテン，お゙よび 2-ブテンとイソブチレ ンの反応によるブロビレンと 2-メチル-2-ブテンなどが生成し， さらにこれらの二重結合異性化物や高次のメタセシス生成物む生 ずる。転化率が比較的高くなった場合汇は图 4 亿示すように，む しろ 2-ブテンの関与する生成物の方が多量飞生成し，一次不均 化の選択率はきわめて低くなるが，この点に間しては後で考光る ことにする。いま，転化率が比較的小さい範囲のデータから転化 事0への外挿を行なって，一次メタセシスの初速度比の推算を問 題としているので，2-ブテンおよびその関与するメタセシス生成 物対象外となり，考慮しなくてもよいといえる。また，この研 究では，オレフィンを水秦化したのちに分析を行なったので，メ タセシス生成物とその二重結合翼性化物は一緒に定量されるが， 転化率 0への外择を行ならので，一次メタセシス生成物の二重結 合異性化物をる一次メタセシス生成物と見なして，なんら差し支 えないはずである。

2-ブテンーイソブチレン系炕和いては，2-ブテン同志のメタセ シスは，見かけ上の反応がある場合でも，シスートランスの異性化 となるので，一次不均化としては，2-ブテンとインブチレンのメ タセシスによるプロピレンと 2-ィチル-2-プテン，およびイソブ チレン 2 分子からのエチレンと 2,3-ジメチル-2-ブテンの生成を 考えればよい。異性化反応仗よる生成物との関保は，1ーブテンー イソブォレン系の場合と同様に考えられる。

1-ブテンーイソブチレン系の反応結果を図 1 亿示す。図の横軸 はイソブチレン転化率，縦軸は一次メタセシスの生成物瀑度であ る。これらの曲線の勾配のイソブチレン転化率 0 への外挿値の比 がそそれそれのメタセシスの初速度比を与える。このよ5にして 求めた初速度比は

$$
r_{1 \mathrm{~B}-1 \mathrm{~B}}: r_{1 \mathrm{~B}-\mathrm{iB}}: r_{{ }_{\mathrm{B}-i \mathrm{~B}}}=90: 50: 1
$$

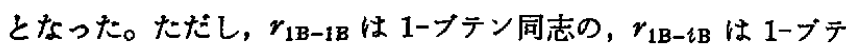
ンとイソブチレンの， $r_{l \mathrm{~B}-1 \mathrm{~B}}$ はイソブチレン闹志のメタセシス の初速度を表わするのとする。

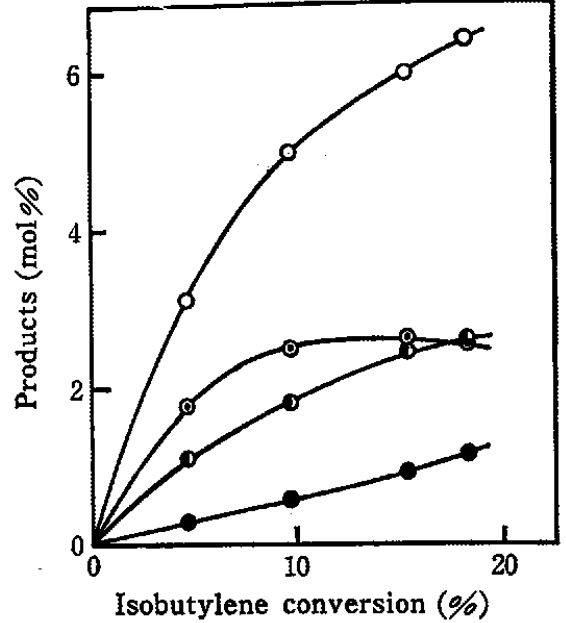

Fig. 1 Plots of primary disproportionation products against isobutylene conversion in the reaction of 1-butene with isobutylene

Temperature : $450^{\circ} \mathrm{C}$

Feed ratio of 1-butene to isobutylene $=1: 1$

$\mathcal{O}:$ Ethylene, $\bigcirc:$ Normal-hexenes,

: : 2-Methylpentenes, $: 2,3$-Dimethylbutenes $\times 10$

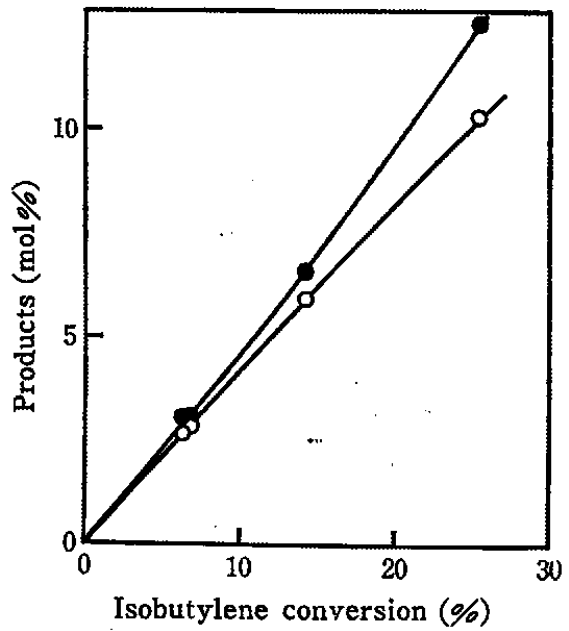

Fig. 2 Plots of primary disproportionation products against isobutylene conversion in the reaction of $c i s-2$-butene with isobutylene

Temperature : $450^{\circ} \mathrm{C}$

Feed ratio of cis-2-butene to isobutylene $=1: 1$

$O:$ Isoamylenes, $: 2,3$-Dimethylbutenes $\times 100$

cis-2-ブテンーイソブチレン系, 扰よび trans-2-ブテンーイ》 ブチレン系のインブチレン転化率と一次メタセシス生成物の関保 を図 2 捛よび図 3 亿示す。これらの図からつぎに示す初速度比が 求められる。

$$
\begin{aligned}
& r_{C \mathrm{~B}-\ell \mathrm{B}}: r_{\ell \mathrm{B}-\ell \mathrm{B}}=100: 1 \\
& r_{t \mathrm{~B}-\ell \mathrm{B}}: r_{\ell \mathrm{B}-\ell \mathrm{B}}=120: 1
\end{aligned}
$$

ただし， $r_{c \mathrm{~B}-t \mathrm{~B}}$ はcis-2-ブテンとイソブチレンのメタセシスの初 速度， $r_{t \mathrm{~B}-t_{\mathrm{B}}}$ はt trans-2-ブテンとイソブチレンのメタセシスの初 速度である。

式 1〜3の関係は，それでれ別々の系について，独立に導びか れたものであり，また反応系存在するオレフィンの種類によっ 


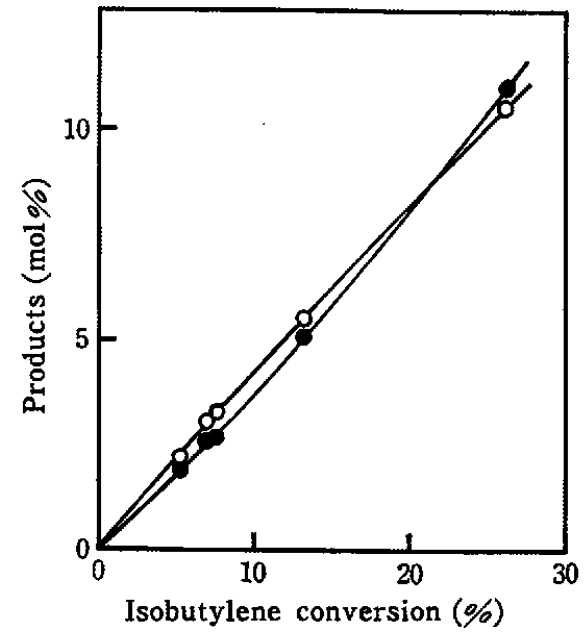

Fig. 3 Plots of primary disproportionation products against isobutylene conversion in the reaction of trans-2-butene with isobutylene

Temperature : $450^{\circ} \mathrm{C}$

Feed ratio of trans-2-butene to isobutylene $=1: 1$

$O$ : Isoamylenes, $: 2,3-D i m e t h y l b u t e n e s \times 100$

て，触媒の活性が変化する ${ }^{37 \eta}$ 之考えられるので，それぞれの比

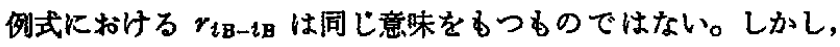
後で述べるよ5に，3 種の 2 成分系直鎖ブテンーインブチレン系 の反応においては，インブチンン同志の反応生成物である 2,3ジチルブテン類の生成速度は実質上等しいと見なし得るので， 式 1〜3中の $r_{i \mathrm{~B}-i \mathrm{~B}}$ 忙実質的には等しいと考えられる。したが って，2種の 2-ブテンとイソブチレンとのメタセシスの初速度 には大きな差はなく,またその初速度は同一条件下の 1-ブテンー イソブチレンのメタセシスの初速度より速いといえる。また，2ブテンーイソブチレンの反応速度が，イソブチレン同志の反応速 度にくらへてて，きわめて速いことが明らかになったが，このこと は，2-ブテンとインブチレンの共不均化によってインフミレンを 合成することを自的とする場合にはきわめて好都合であるとい兄 る。

上飞述べたように，直鎖ブテンーイソブチレン系におけるメタ セシスの初速度比はプロピレンーインブチレン系名の場合とよく 似た傾向を示している。このことから，プロピレンーインブチレ ン系において考察した結果の，オレフィンの組み合わせの異なる メタセシスを促進できる活性点の数はそれぞれの組み合わせごと に異なっているとする見方が，この直鎖ブテンーインブチレン系 の場合炕も，そのままあてはまるるのと考えることができる。

\section{2 直鎮ブテン類-イソブチレンの共不均化における原料比の} 影喽

触媒量 $2.00 \mathrm{~g}$, 反応温度 $450^{\circ} \mathrm{C}$ ，オレフィン流量 $18 \mathrm{l} / \mathrm{hr}$, NTP の一定条件のもとで，直銷ブテンーイソブチレン 2 成分系の原料 比率を変化させた場合の生成物の変化を図 4，5，6亿示す。

1-ブテンーインブチレン系の結果は，図4に示されるように， 原料組成のほぼ全範囲にわたって, 一次メタセシスの生成物より も 1-ブテンの異性化生成物である 2-ブテンの関与するメタセシ 不生成物の方が多量に生成した。これは後で述べる(図 8)ような 1ーブテン $\rightarrow 2$-ブテンの異性化速度がかなり速いことを示唆するも

7) F. Pennella, R. L. Banks, J. Catal., 31, 304(1973).

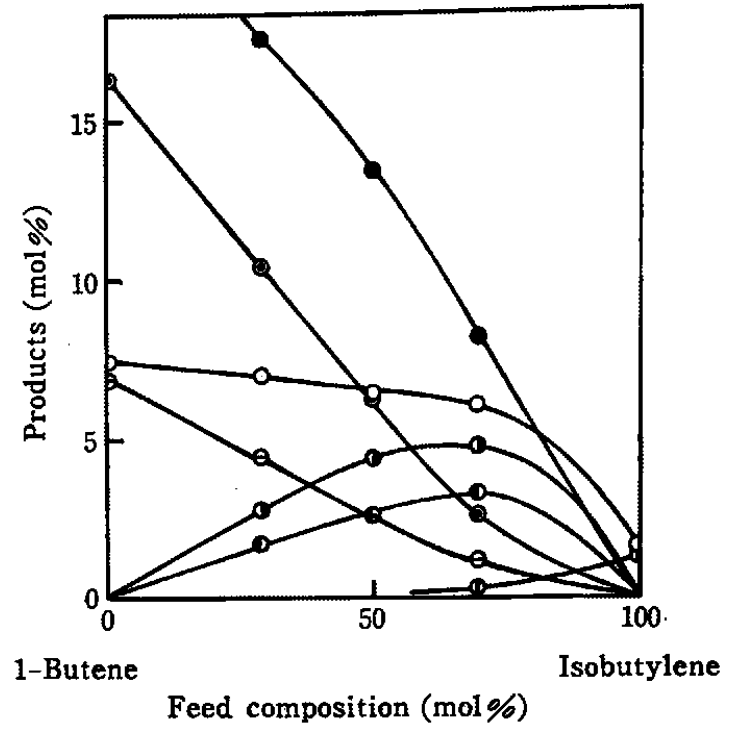

Fig. 4 Effect of feed composition on the product distribution in the disproportionation of 1-butene with isobutylene

Temperature $: 450^{\circ} \mathrm{C}$, Catalyst $: 2.00 \mathrm{~g}$,

Feed rate $: 18 l / \mathrm{hr}$, NTP

$\bigcirc$ : Ethylene, : Propylene, $\odot$ : Normal pentenes,

( : Isoamylenes, $\Theta$ : Normal hexenes,

(D : 2-Methylpentenes, (1) : 2,3-Dimethylbutenes

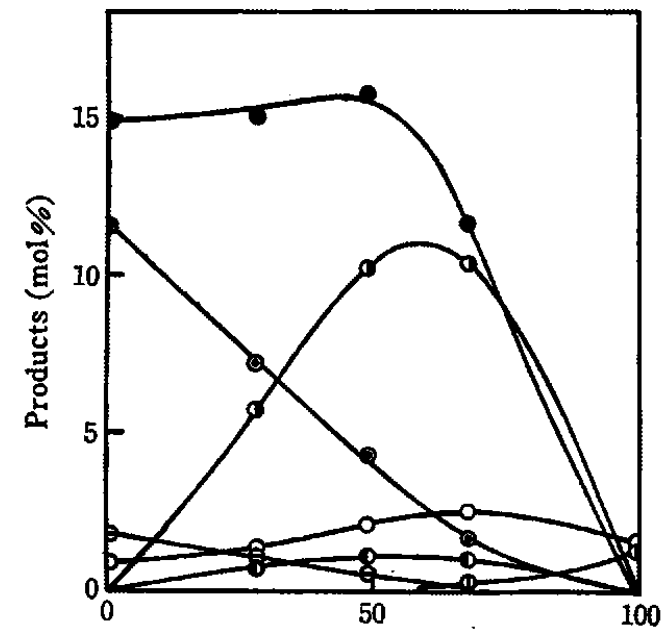

cis-2-Butene

Isobutylene

Feed composition (mol\%)

Fig. 5 Effect of feed composition on the product distribution in the disproportionation of cis-2-butene with isobutylene

Temperature $: 450^{\circ} \mathrm{C}$, Catalyst $: 2.00 \mathrm{~g}$,

Feed rate $: 18 l / h r$, NTP

$\bigcirc:$ Ethylene, : Propylene, $\bigcirc:$ Normal pentenes,

0 : Isoamylenes, $\Theta$ : Normal hexenes,

D : 2-Methylpentenes, (1) : 2,3-Dimethylbutenes

のである。またこの哄性化の平衡が 2-ブテンの僋に大きく攧

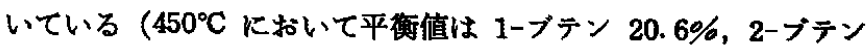
79.4\%) こと，すでに述べたよ5に，2-ブテンーインブチレンの メタセシスは 1-ブテンーイソブチレンのメダスより速いこ と，さらに後で述べるように，1-ブテンー2-ブテンのメタセシス は 1-ブテン同志のメタセシスよりかなり速いことなどがその原 


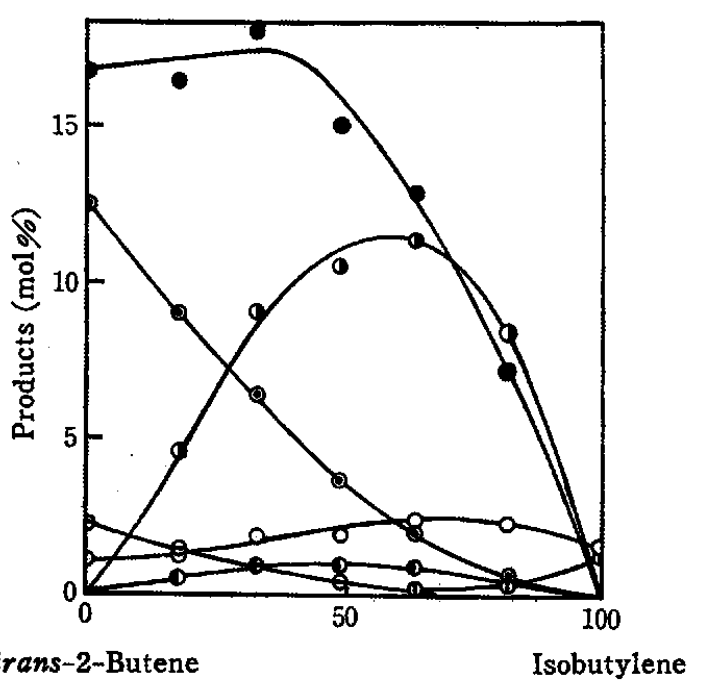

Feed composition (mol\%)

Fig. 6 Effect of feed composition on the product distribution in the disproportionation of trans-2-butene with isobutylene

Temperature $: 450^{\circ} \mathrm{C}$, Catalyst $: 2.00 \mathrm{~g}$,

Feed rate $: 18 \mathrm{l} / \mathrm{hr}$, NTP

$\bigcirc$ : Ethylene, : Propylene, $\bigcirc$ : Normal pentenes,

(1) : soamylenes, $\Theta$ : Normal hexenes,

(D : 2-Methylpentenes, (1) : 2,3-Dimethylbutenes

因として考えられる。

図5に示す cis-2-ブテンーインブチレン系の結果と図 6 の trans-2-ブテンーイソブチレン系の結果とは，ょく做た生成物分 布を与えている。この結果は, 2 種の 2-ブテンーインブチレン のメタセシスの初速度には大差がないことから予想し得るもので あり,さらK反応の過程でシス※トランスの異性化す起こるの で，原料による違いは反応の進行にとるない，さらに小さくなる

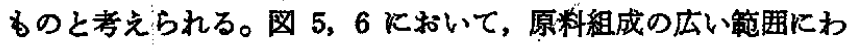
たって，1ーブテンの関与するメタセシスの生成物が顥著に認めら れるが，これは前に述べた 1ーブテンーインブチレン采の場合と 同様に，この反応条件下の二重結合異性化为かなり速いことを示

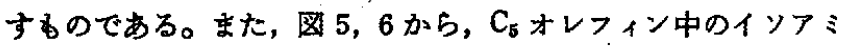
レン選択率を高めるためには,イ゙ソブチレンの比較的高濃度 $(60$ ～80 mol\%）の原料を用いることが望ましいといえる。このよう なイソブチレン高漊度では, 一次メタセシスによって生成したブ ロピレンとインブチレンからエチレンとインフミレンが生成する 反応すかなり進行していることが図 5，6 から明らかである。

因 4，5，6 に示すよらに, 1-ブテンーイソブチレン系と 2-ブ テンーイソブチレン系の共不均化飞おける主生成物の分子種はま ったく同じであり，それらの間の量的関係が異なっているにすぎ ない。ここで用いた触媒のょうに，二重結合の異性化活性のかな り高い触媒を用いるのでは，直鎖ブテンを含せ系の不均化におい て筫択性の高い反底結果を期待することは難かしい。これに反し て；ブロピレン単独の，あるいはブロピレンーイソブチレン系の 反応では，原料オレフィンの二重結合移動は見かけ上起こらない ので, 生成したブテン類, あるいはイソフミレン類を脱水素し て，シェン類に変換する場合のよ5に，生成物の二重結合の位臣 が問題にならない堭合には，不㚬化条件下における巽性化は重大 な問題にはならなかった。面鎖ブテンーイソブチレン系の共不均
化を実用的な見地からみれば，反灾条件下で実䝷的な異性化が起 こらないことが望ましい。この異性化が避けられないのであれ ば，できるだけ異性化活性の低い触媒を，異性化の起こり難い条 件で使用しなければならない。

プロピレンーイソブチレン系に拐いては，原料組成によって， $\mathrm{WO}_{3}-\mathrm{SiO}_{2}$ 触媒の活性が变化すると考兄られる結果が得られたす が直鎖ブテンーイソブチレン系の場合には, この現象は明らかに は認められない。図 4，5，6 扎よび既報9の結果から, 同一反応 条件下における原料中のイソブチレン裖度と 2,3 -ジメチルブテ ン類の生成量の関係を一つの図に示せば図 7 のらになる。この 図では，3種の直鎖ブテンーイソプチレン系の結果は, 一つの曲 線で表わされ，三つの系化いて，2，3-ジメチルブテン類の生成 速度がほぼ等しいことを示している。一方, ブロピレンーインブ チレン系のプロットは下にずれる。この結果から既報と同様の考 察によって，この反応条件下の $\mathrm{WO}_{3}-\mathrm{SiO}_{2}$ 触媒は, 直鎖ブテンー イソブチレン系に扣いては, 同一イソブチレンモル襄度のプロピ レンーイソブチレン系に拈けるよりる高活性の状態にあり, しか もその 3 種の系において，触媒の活性状態にほとんど差がないと いうことができる。

\subsection{1-プテンの不均化と異性化および直鎖プテン問のメタセ シス初速度比}

遮鎖ブテンーイソブチンン系の共不均化においては, 二重結合 異性化が生成物組成に重大な影㸷を与えることがわかった。ま た，1-ブテン同志のメタセシスにくらべて，1-ブテンと 2-ブテ ン゙のメタセシスがかなり速いと推定される結果が得られた。そこ で, 1-ブテン単独の反応によって, その不均化と巽珄化の関係を 調べ，また，原料モル比 $1: 1$ の 1-ブテンー2-ブテン系の反応に よって，おのおののメタセシスの初速度比を求めた。

反応温度 $450^{\circ} \mathrm{C}$ に怙いて; 同し反応管を用いて, 触媒量 $(0.10$ $0.50 \mathrm{~g})$ および流量 $(10,20 \mathrm{l} / \mathrm{hr}, \mathrm{NTP})$ を変化させて行なった1一 ブテンの反応結果を図 8 亿示す。この図の横軸は $W / F(W:$ 触媒 量, $F:$ 原料流量), 綎軸は不均化率および異性化率を表わす。た だし，不均化率は一次メタセシス生成物のエチンン执よび直鎖へ

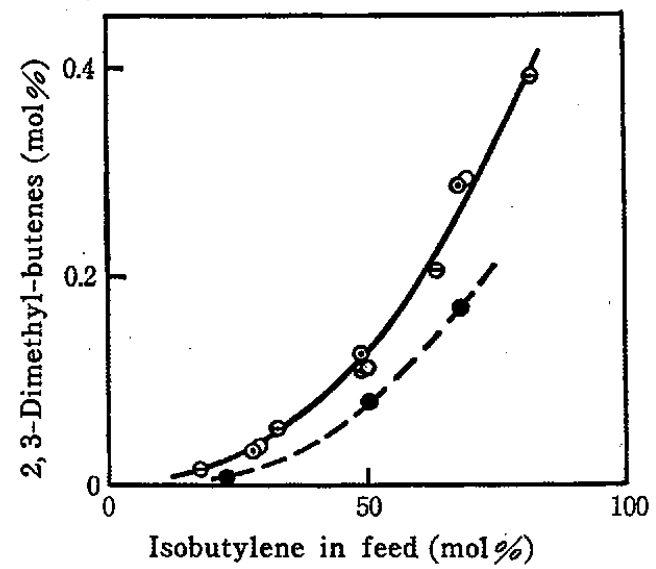

Fig. 7 Relationship between feed composition and the yield of 2,3-dimethylbutenes in the disproportionation of $\bigcirc$ 1-butene and isobutylene, $\odot$ cis-2butene and isobutylene, $\ominus$ trans-2-butene and isobutylene, and propylene and isobutylene

Temperature $: 450^{\circ} \mathrm{C}$, Catalyst $: 2.00 \mathrm{~g}$, Feed rate $: 18 l / h r, N T P$ 


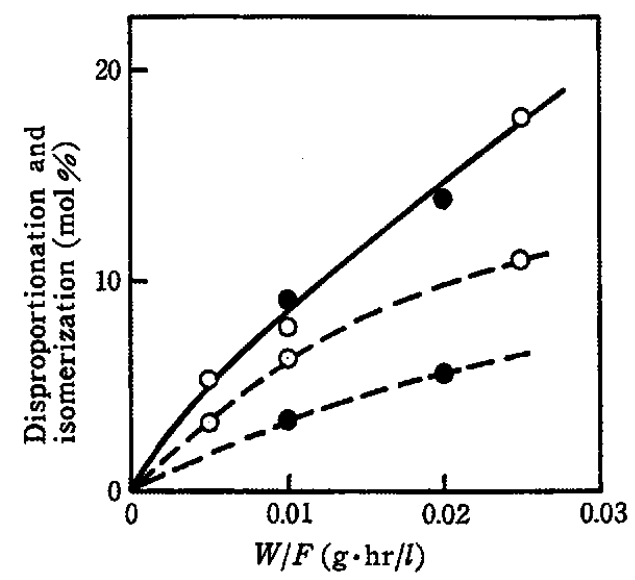

Fig. 8 Disproportionation and isomerization of 1-butene on $\mathrm{WO}_{3}-\mathrm{SiO}_{2}$ catalyst at $450^{\circ} \mathrm{C}$

- - - : Disproportionation, — : Isomerization

Feed rate : $10 \mathrm{l} / \mathrm{hr}, \bigcirc 20 \mathrm{l} / \mathrm{hr}$

キセン類の合計の生成率で表わし, 異性化率は, 異性化生成物の cis- および trans-2-ブテンおよび 2-ブテンが変化したるのと考 えられるプロピレンの合計の生成率で表わした。図8から明らか に，実験範囲において， $\mathrm{WO}_{3}-\mathrm{SiO}_{2}$ 触媒上における 1-ブテンの異 性化速度は原料の線速度に依存しないが, メタセシス速度の線速 度依存性はきわめて吂いことがわかる。このようなメタセシス速

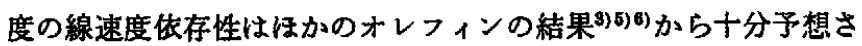
れ得るるのである。このよ5に, 1-ブテンのメタセシスと異性化 の線速度依存性が異なるので，ある条件のもとでこれらの反応速 度を比較してむあまり意味がないが，たと流，図 8 中の原料流 量 $20 \mathrm{l} / \mathrm{hr}$, NTP (空管線速度 $4.8 \mathrm{~cm} / \mathrm{sec}$ ) の場合の, メタセシス と異性化の初速度の比は，およそ $2: 3$ である。

上に述べた結果から， $\mathrm{WO}_{8}-\mathrm{SiO}_{2}$ 触媒を用いるオレフィンの不 均化のさいに線速度を大きくすれば, 異性化速度は変わらない が，不均化速度は線速度ととるに増すことが予測されるので, 容 易に大きな線速度をとることができる工業規模の装監において は，実験室の結果と比較して，不均化の選択性は高くなるるのと 性えられる。

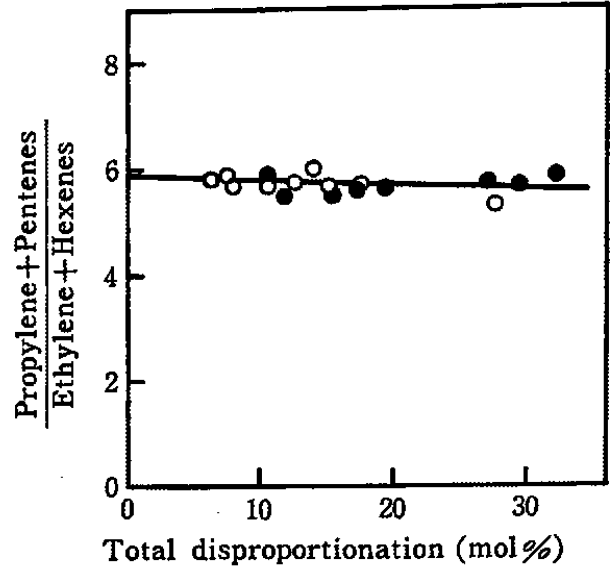

Fig. 9 Ratio of initial rates in the disproportionation of 1-butene with 2-butenes

Temperature $: 450^{\circ} \mathrm{C}$

Feed ratio of 1 -butene to 2 -butene $=1: 1$

Feed : $\bigcirc$ 1-Butene and cis-2-butene

1-Butene and trans-2-butene

直鎖ブテン間のメタセシスの初速度比を求めるために，原料モ ル比 1：1の1-ブテンーcis-2-ブテン系および, 1-ブテンーtrans2 -ブテン系について, 反応温度 $450^{\circ} \mathrm{C}$, 流量 $18 \mathrm{l} / \mathrm{hr} \cdot \mathrm{NTP}$, 触媒 量 $0.4 \sim 1.5 \mathrm{~g}$ による実験を行なった。その結果について, 図 9 に示す上5に，横軸に全不均化率 ( $\mathrm{C}_{*}$ 以外の宸化水素の生成率) を，縦軸にプロピレン+直鎖ベンテン類の生成率とエチレン十直 鎖へキセン類の生成率の比をとってプロットした。このブロット は cis-およびtrans-2-ブテンを含む両采で一整した。そしてっこ のブロットの転化率0への外挿值は，1-ブテン同志のメタセシス と 1-ブテン-2-ブテン間のメタセシスの初速度此を表わするので ある。すなわち, この反応条件において， $r_{1 B-C B}: r_{1 B-1 B}$ および $r_{1 B-t B}: r_{1 B-1 B}$ はいずれす注活 $6: 1$ であることがわかる。ただ し, $r_{1 \mathrm{~B}-\mathrm{CB}}$ は 1-ブテンと cis-2-ブテンの, $r_{1 \mathrm{~B}-t \mathrm{~B}}$ は 1-ブテンと trans-2-ブテンのメタセシスの初速度をそれぞれ表わするのとす ๖。

\title{
Disproportionation of Mixtures of $\mathrm{C}_{4}$ Olefins over Tungsten Oxide-Silica Catalyst
}

\author{
Tadao Takahashi \\ National Research Institute for Pollution and \\ Resouces; Kawaguchi-shi 332 Japan
}

Disproportionation of the equimolar mixtures of two $\mathrm{C}_{4}$ olefins has been investigated over a $\mathrm{WO}_{3}-\mathrm{SiO}_{2}$ catalyst at a total pressure of about $1 \mathrm{~atm}$ and at $450^{\circ} \mathrm{C}$ in a quartz reactor. The ratios of the initial rate of each primary metathesis were determined : in the reaction of 1butene with isobutylene, $r_{1 \mathrm{~B}-1 \mathrm{~B}}: r_{1 \mathrm{~B}-\ell \mathrm{B}}: r_{t \mathrm{~B}-\ell \mathrm{B}}=90: 50: 1$, in the reaction of cis-2-butene with isobutylene, $r_{c \mathrm{~B}-i \mathrm{~B}}: r_{i \mathrm{~B}-i \mathrm{~B}}=100: 1$, and in the reaction of trans-2-butene with isobutylene, $r_{t \mathrm{~B}-\imath_{\mathrm{B}}}: r_{i \mathrm{~B}-i \mathrm{~B}}=120: 1$. In the reactions of 1-butene with cis-2-butene and 1-butene with trans-2-butene, the ratios of initial rates were $r_{1 \mathrm{~B}-1 \mathrm{~B}}: r_{1 \mathrm{~B}-\mathrm{CB}}=r_{1 \mathrm{~B}-1 \mathrm{~B}}: r_{1 \mathrm{~B}-t \mathrm{~B}}=1: 6$.

Under the conditions of these experiments, the disproportionation was accompanied with the migration of double bonds, which affected the distributions of products considerably. As shown in Fig. 8, the linear velocity of feed affected the rate of disproportionation but did not change the rate of isomerization. The higher linear velocity was preferable to the selective disproportionation. In the reaction of 2 -butenes with isobutylene, high selectivity to isoamylenes was attained when the concentration of isobutylene in the feed was considerably high. 